\title{
Analisis Penerapan Model Business Intelligence pada Aplikasi Payment Point Online Banking dalam Meningkatkan Strategi Pemasaran (Studi Kasus: Aplikasi ApotikKuota)
}

\section{Analysis of Business Intelligence Model Implementation in Payment Point Online Banking to Improve Marketing Strategies (Case Study: ApotikKouota Application)}

\author{
ALTESA YUNISTIRA ${ }^{1 *}$, DHOMAS HATTA FUDHOLI ${ }^{1}$
}

\begin{abstract}
Abstrak
Perkembangan bisnis era digital saat ini membuat stakeholder aplikasi ApotikKuota menyadari besarnya tantangan dalam dunia bisnis. Saat ini, data merupakan hal yang berharga dan memiliki nilai penting sehingga membuat stakeholder ApotikKuota memiliki fokus pada penanganan data yang baik. Data tersebut antara lain berupa transaksi penjualan, pelanggan, serta data lainnya yang akan berguna dalam pengambilan keputusan dalam penerapan strategi pemasaran. Selama ini, penanganan pemasaran didasarkan pada intuisi stakeholder tanpa melihat manfaat dari proses analisis data yang ada. Business intelligence menjadi solusi bagi perusahaan atau organisasi untuk menganalisis dan menyediakan akses ke data guna membantu mengambil keputusan secara lebih baik. Dalam penelitian ini, peneliti merancang dan membangun model business intelligence untuk mendukung strategi pemasaran pada bisnis payment point online bank. Penelitian ini dilakukan untuk mengkaji penerapan business intelligence dengan membuat dashboard pelaporan dan online analytical processing untuk membantu stakeholder mengambil keputusan. Hasil penelitian ini berupa penyajian informasi yang dibutuhkan oleh stakeholder dalam proses pengambilan keputusan dengan mengacu pada penerapan strategi bauran pemasaran (marketing mix) yang memiliki komponen 4P, yaitu price, product, place, dan promotion.
\end{abstract}

Kata Kunci: business intelligence, dashboard, payment point online bank, strategi pemasaran, pengambilan keputusan

\begin{abstract}
The development of today's digital business makes ApotikKuota stakeholders realize the magnitude of the challenges in the business world. At present, data is valuable and has a significant value that makes ApotekKuota stakeholders focus on data handling best practices. The data includes sales, customers, and others that will be useful in making decisions in implementing marketing strategies. Presently, the stakeholders managing marketing decision based on intuition without seeing the benefits of the existing data analysis process. Business intelligence is a solution for companies or organizations to analyze and provide access to data to make better decisions. In this study, researchers designed and built a business intelligence model to support marketing strategies in the payment point online banking business. We examine the implementation of business intelligence by creating a reporting dashboard and online analytical processing to help stakeholders make decisions. The results of this study are the presentation of information needed by stakeholders in the decision-making process by referring to the application of the marketing mix strategy which has a $4 P$ component, namely price, product, place, and promotion.
\end{abstract}

Keywords: business intelligence, dashboard, decision-making, marketing strategy, payment point online bank

\footnotetext{
${ }^{1}$ Departemen Informatika, Universitas Islam Indonesia, Yogyakarta, Indonesia

* Penulis Korespondensi; Surel: altesayunistira@gmail.com
} 


\section{PENDAHULUAN}

Payment point online bank (PPBO) adalah sistem pembayaran daring yang memanfaatkan fasilitas perbankan. Pembayaran yang dimaksud bisa bermacam-macam, mulai dari tagihan listrik, asuransi kesehatan, telepon, pulsa, internet, paket data, asuransi, tiket pesawat dan kereta api, kartu kredit, multifinance, hingga kupon permainan digital dan transportasi daring. Selain itu, PPOB juga bekerjasama dengan lembaga switching sebagai pengatur lalu lintas data serta toko atau loket untuk melayani pelanggan. PPOB dapat menjadi bisnis yang menguntungkan, di satu sisi, PPOB memberi kemudahan kepada masyarakat untuk memenuhi kebutuhan aneka pembayaran (Tim SBF 2018).

ApotikKuota merupakan aplikasi PPOB berbasis web dan Android yang melayani beberapa transaksi seperti pembelian pulsa, paket telpon, paket data internet, pembayaran listrik, serta pembelian produk uang digital seperti GoPay dan OVO. ApotikKuota berdiri sejak 1 Oktober 2016 dan berbasis di Jakarta. Aplikasi berbasis Android diluncurkan pertama kalinya pada 5 November 2017. Saat ini, kesadaran bahwa data merupakan hal yang berharga membuat stakeholder ApotikKuota memiliki fokus pada penanganan data yang baik. Data yang terlibat misalnya transaksi penjualan, pelanggan, serta data lainnya yang akan berguna dalam pengambilan keputusan dalam penerapan strategi pemasaran. Selama ini, penanganan pemasaran hanya didasarkan pada intuisi stakeholder tanpa melihat manfaat dari proses analisis data yang ada pada ApotikKuota. Alur bisnis proses pada aplikasi ApotikKuota dapat dilihat pada Gambar 1.

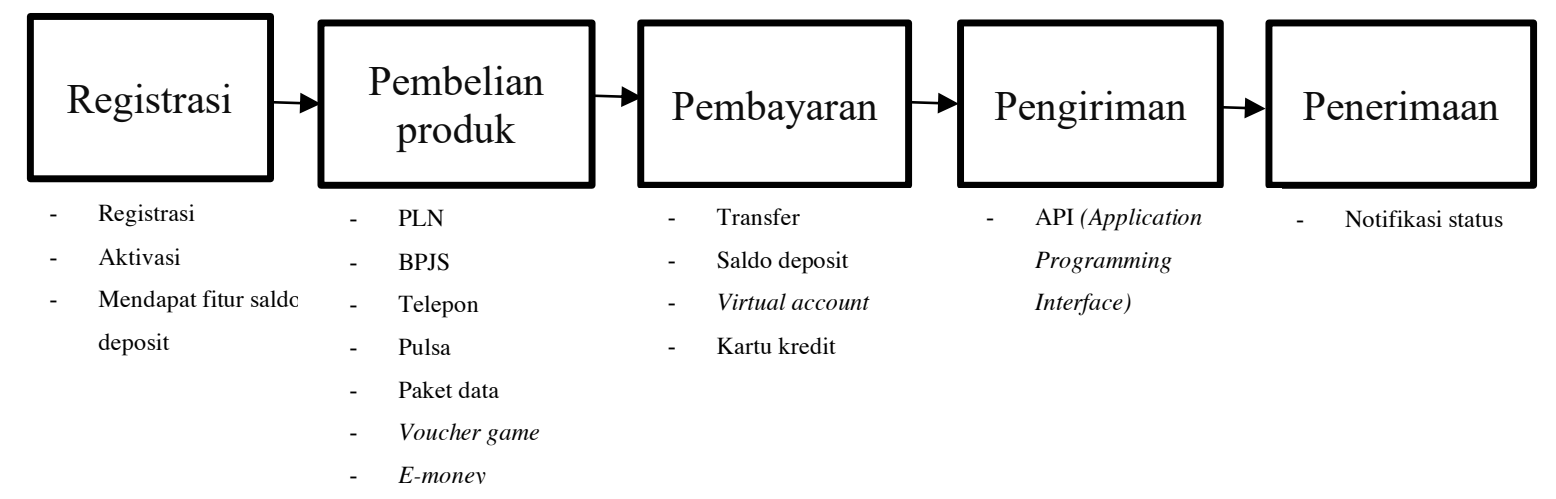

Gambar 1 Alur proses bisnis ApotikKuota.

Dengan proses analisis terhadap data transaksi penjualan, pihak manajemen mendapatkan informasi yang digunakan untuk keperluan manajemen dalam menentukan sejumlah kebijakan. Beberapa kebijakan tersebut adalah menentukan strategi promosi, meningkatkan pengguna, menentukan jumlah produk yang harus disediakan, melihat tren penjualan dari sisi produk dan pengguna, serta tingkat profitabilitas suatu produk. Selain itu, proses analisis terhadap data transaksi penjualan, dapat menggali keterkaitan antara produk dan konsumen. Hal ini dapat digunakan untuk menentukan strategi pemasaran. Oleh karena itu, peneliti merancang dan membangun model business intelligence $(\mathrm{BI})$ untuk mendukung strategi pemasaran pada bisnis PPOB.

Dalam BI, dikenal online analytical processing (OLAP) yang merupakan pendekatan untuk menyajikan jawaban dari permintaan proses analisis yang bersifat dimensional secara cepat, berupa desain, aplikasi dan teknologi yang dapat mengoleksi, menyimpan, memanipulasi suatu data multidimensi untuk tujuan analisis. OLAP merupakan kunci dari BI dan digunakan untuk menganalisis data dan informasi yang kemudian akan digunakan sebagai dasar pengambilan keputusan atau sistem penunjang keputusan pada sebuah organisasi atau perusahaan. Pada penelitian ini, peneliti merancang dan membangun model BI, melakukan pengkajian penerapan BI dengan membuat dashboard pelaporan dan OLAP untuk membantu 
pihak manajemen atau stakeholder mengambil keputusan. Penelitian ini juga diharapkan dapat membantu manajemen dalam mengambil keputusan yang berhubungan dengan strategi pemasaran, sehingga dapat menyajikan informasi berkaitan dengan strategi bauran pemasaran.

\section{METODE}

\section{Prosedur Penelitian}

Prosedur dalam penelitian ini (Gambar 2) dilakukan dengan mendeskripsikan setiap urutan secara sistematis dan logis sehingga dapat menjari pedoman yang jelas untuk menyelesaikan permasalahan.

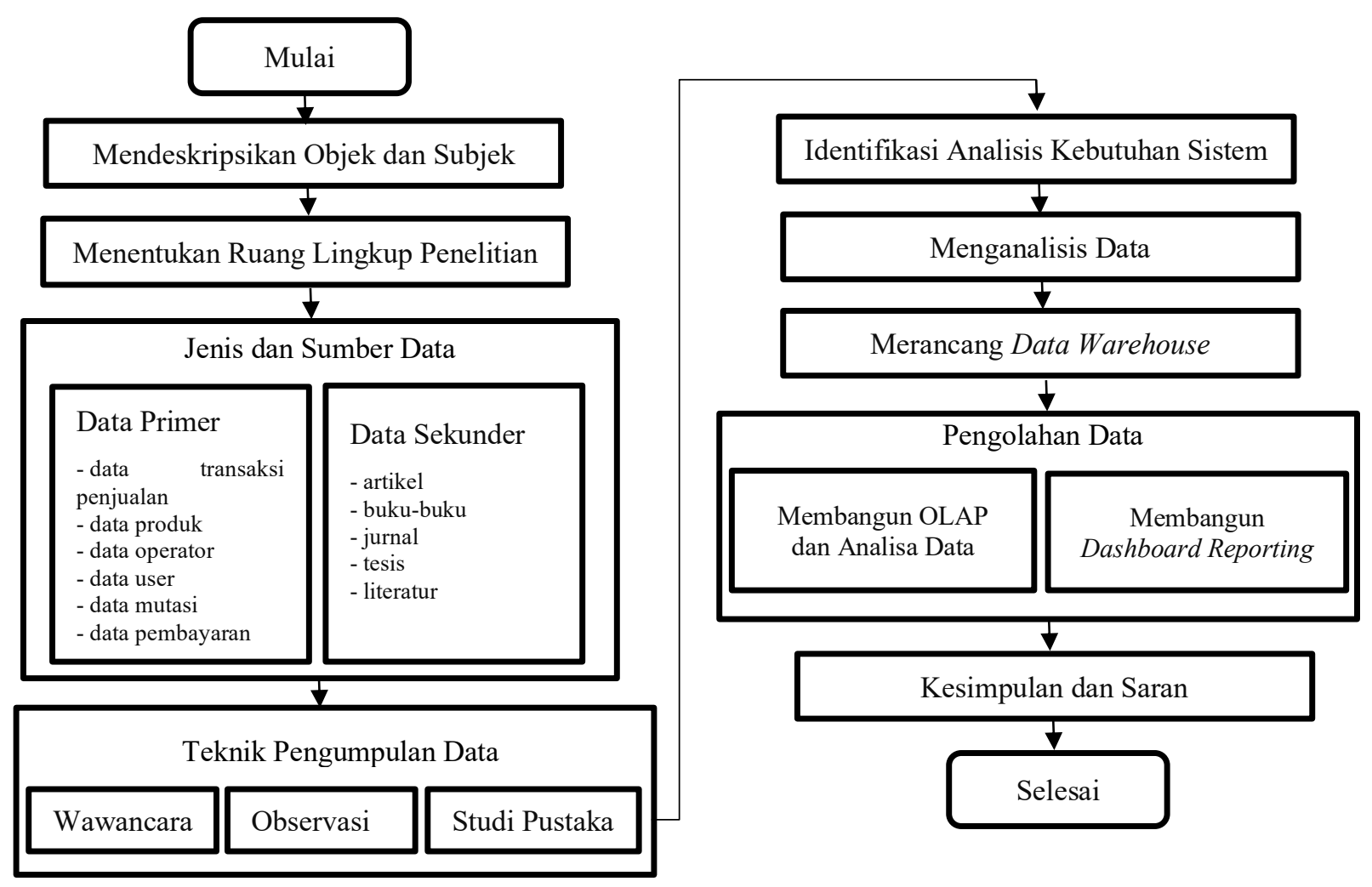

Gambar 2 Metode penelitian.

\section{Objek dan Subjek Penelitian}

Objek penelitian kali ini adalah PPOB bernama ApotikKuota, sedangkan subjek penelitian ini adalah analisis penerapan data transaksi penjualan dan data pelanggan pada aplikasi PPOB ApotikKuota untuk meningkatkan strategi pemasaran. Stakeholder membutuhkan hasil pengolahan data laporan transaksi sebagai dasar pengambilan keputusan dalam menerapkan strategi pemasaran guna pengembangan bisnisnya tersebut.

\section{Ruang Lingkup Penelitian}

Parameter yang digunakan mengacu pada teori strategi pemasaran dan penerapanya dalam BI. Kemudian, beberapa aspek dalam strategi pemasaran tersebut akan diterapkan pada BI dengan mengikuti teori dan langkah-langkah penerapannya. Data yang akan digunakan dalam penelitian ini merupakan data transaksi penjualan pada tahun 2016 hingga 2019. Untuk menghasilkan analisis yang baik mengenai kinerja penjualan, OLAP dipilih. Penelitian ini dilakukan hingga menghasilan dashboard pelaporan serta evaluasi dampak yang dihasilkan setelah penerapan BI. 


\section{Identifikasi dan Analisis Kebutuhan Sistem}

Tahap identifikasi dan analisis kebutuhan dilakukan untuk mengetahui permasalahan dan kebutuhan stakeholder terhadap aplikasi yang akan dikembangkan. Sebelum melakukan penerapan BI, hal tersebut perlu dilakukan agar aplikasi yang akan dikembangkan sesuai dengan kebutuhan stakeholder. Hasil identifikasi tersebut berupa proses bisnis yang berjalan pada aplikasi ApotikKuota, serta hasil pemetaan keempat elemen pada strategi bauran pemasaran. Hasil identifikasi tersebut akan digunakan untuk penerapan BI berupa dashboard pelaporan dan sebagai acuan stakeholder dalam pengambilan keputusan strategi pemasaran. Setelah seluruh informasi tersebut diperoleh, empat komponen dalam strategi bauran pemasaran berikut dilakukan.

- Penerapan strategi produk (Product): Produk yang tersedia pada aplikasi ApotikKuota pastilah memiliki transaksi penjualan terbanyak dan terendah. Stakeholder diharapkan mampu mengambil keputusan apakah perlu dengan menambahkan beberapa produk layanan lainnya atau tidak.

- Penerapan strategi Harga (Price): Dalam penerapan strategi harga, aplikasi ApotikKuota saat ini telah menerapkan harga khusus kepada pelanggannya yang berstatus reseller. Hal ini juga berkaitan erat dengan strategi produk, yaitu strategi harga dapat diterapkan untuk produk-produk yang kurang diminati. Akan tetapi, hal ini juga dipengaruhi dari promosi yang dilakukan oleh provider dari produk tersebut.

- Penerapan Strategi Promosi (Promotion): Dalam penerapan strategi promosi, stakeholder dapat mengombinasikan penerapannya dengan strategi pemasaran lainnya. Sebagai contoh, dalam penerapan strategi distribusi, stakeholder harus menerapkan strategi promosi dengan memberikan hadian poin tertentu terhadap transaksi penjualan pengguna berstatus reseller, uang kembali untuk deposit awal sebagai reseller, dan beberapa opsi lainnya yang dapat dilakukan oleh stakeholder.

- Penerapan Strategi Distribusi (Place): Dalam penerapan strategi distribusi, aplikasi ApotikKuota telah menerapkan jalur distribusinya melalui web dan aplikasi Android (Apotikkuota). Berdasarkan Kotler and Armstrong (2012), pelanggan berstatus reseller merupakan salah satu jalur distribusi aktif yang saat ini dimiliki oleh aplikasi ApotikKuota. Dengan memperkuat penerapan strategi harga dan promosi, jalur distribusi oleh pelanggan berstatus reseller ini dapat meningkatkan transaksi penjualan.

\section{Analisis Data}

Berdasarkan analisis pada tahap sebelumnya, dapat ditarik simpulan bahwa dibutuhkan sebuah dashboard sistem yang dapat menyajikan informasi transaksi dalam bentuk visualisasi laporan. Sistem tersebut dibuat menggunakan Microsoft PowerBI sebagai perangkat perancangan data warehouse dan analisis model dimensional serta penyajian analisis data dalam bentuk visualisasi laporan. Dari tiga puluh lima tabel pada ApotikKuota, terdapat lima tabel yang akan digunakan dalam perancangan model, yaitu pengguna, transaksi, voucher, operator, dan target.

\section{Perancangan Data Warehouse}

Langkah selanjutnya adalah perancangan data warehouse dengan merancang basis data logikal serta menentukan skema data warehouse yang akan digunakan. Kemudian, dengan tabel fakta dan tabel dimensi diproses melalui tahap extract, transform, load (ETL). Setiap model dimensi terdiri atas sebuah tabel dengan sebuah komposit primary key yang disebut dengan tabel fakta, serta satu himpunan tabel yang lebih kecil disebut dengan tabel dimensi. Setiap tabel dimensi memiliki sebuah simple primary key yang merespons tepat satu komponen primary key pada tabel fakta. Dengan kata lain, primary key pada tabel fakta terdiri atas dua atau lebih foreign key. Struktur karakteristik ini disebut dengan skema bintang. Secara umum gambaran model data OLTP digunakan untuk membuat desain data warehouse sebagai dasar dalam melakukan penerapan BI yang terdiri atas beberapa kriteria, yaitu: 
- Memenuhi proses bisnis: proses bisnis disesuaikan dengan kebutuhan pihak stakeholder sebagai pengguna. Dalam hal ini, proses bisnis yang diinginkan adalah menampilkan informasi data transaksi penjualan produk serta data konsumen atau pengguna.

- Memenuhi atribut dari tabel fakta: Berdasarkan proses bisnis yang ada, Tabel 1 merupakan contoh tabel fakta transaksi yang terdiri atas atribut dari tabel dimensi pada penelitian ini.

- Memenuhi tabel dimensi: Setiap tabel diidentifikasi sesuai dengan nama dan atribut yang mendukung tabel fakta. Berikut ini merupakan beberapa tabel dimensi. Tabel 2 hingga Tabel 4 memperlihatkan tabel dimensi produk, pengguna, target, dan waktu yang digunakan pada penelitian ini.

- Memenuhi fakta yang terukur: Dalam melakukan definisi, tabel fakta harus terukur sesuai dengan kebutuhan. Semua fakta harus ditampilkan pada tingkat yang telah ditentukan oleh sumber.

- Melengkapi tabel dimensi: Pada tahap ini. keterangan secara lengkap pada tabel dimensi yang bersifat intuitif dan mudah dipahami oleh pengguna ditambahkan.

- Permodelan data: Model data yang digunakan untuk permodelan data adalah skema bintang. Tabel-tabel dimensi yang membentuk tabel fakta dapat didukung oleh tabel lain yang lebih

Tabel 1 Atribut dan tipe data dari tabel fakta transaksi

\begin{tabular}{llllll}
\hline Atribut & Tipe Data & Atribut & Tipe Data & Atribut & Tipe Data \\
\hline tr_id & int(10) & tr_id_plgn & varchar(64) & tr_retry & tinyint(2) \\
us_id & $\operatorname{int}(10)$ & tr_no_hp & varchar(64) & tr_cek_mutasi & int(10) \\
sv_id & $\operatorname{int}(10)$ & tr_harga & int(12) & tr_status & varchar(32) \\
op_id & int(10) & tr_harga2 & int(12) & tr_opsi & text \\
op_produk & varchar(32) & tr_income & int(6) & tr_tanggal & int(10) \\
op_nama & varchar(64) & tr_rate & int(10) & tr_terkirim & int(10) \\
vo_id & int(10) & tr_pembayaran & varchar(32) & us_reseller & varchar(10) \\
vo_kode & varchar(12) & tr_status_pembayaran & varchar(32) & tgl_char & varchar(10) \\
vo_nominal & varchar(64) & tr_id_pembayaran & varchar(32) & tr_tahun1 & int(4) \\
\hline
\end{tabular}

Tabel 2 Atribut dan tipe data dari tabel dimensi produk

\begin{tabular}{ll}
\hline Atribut & Tipe Data \\
\hline op_id & $\operatorname{int}(5)$ \\
op_nama & $\operatorname{varchar}(64)$ \\
op_produk & $\operatorname{varchar}(32)$ \\
vo_nominal & $\operatorname{varchar}(64)$ \\
\hline
\end{tabular}

Tabel 3 Atribut dan tipe data dari tabel dimensi target

\begin{tabular}{ll}
\multicolumn{2}{l}{ Tabel 4 Atribut dan tipe data dari tabel dimensi pengguna } \\
\hline Atribut & Tipe Data \\
\hline us_id & int(10) \\
us_username & varchar(32) \\
us_name & varchar(32) \\
us_email & varchar(255) \\
us_gender & enum(", 'male', 'female') \\
us_location & varchar(255) \\
us_phone & varchar(16) \\
us_balance & int(10) \\
us_verified & enum('0', '1') \\
us_reseller & enum('active', 'inactive', 'blocked') \\
us_total_order & int(10) \\
us_lastdate & int(10) \\
us_regdate & int(10) \\
tgl_reg & datetime \\
tgl_char & varchar(10) \\
\hline
\end{tabular}

\begin{tabular}{ll}
\hline Atribut & Tipe Data \\
\hline target_id & int(11) \\
target_nominal & bigint(20) \\
tahun & $\operatorname{int}(11)$ \\
\hline
\end{tabular}

Tabel 5 Atribut dan tipe data dari tabel dimensi waktu

\begin{tabular}{ll}
\hline Atribut & Tipe Data \\
\hline date_id & bigint(20) \\
date & date \\
timestamp & $\operatorname{bigint}(20)$ \\
weekend & $\operatorname{char}(10)$ \\
tahun & $\operatorname{tahun}$ \\
day_of_week & char(10) \\
month & $\operatorname{char}(10)$ \\
month_day & $\operatorname{int}(11)$ \\
year & $\operatorname{int}(11)$ \\
week_starting_monday & $\operatorname{char}(2)$ \\
tgl_char & $\operatorname{varchar}(10)$ \\
\hline
\end{tabular}


detail dan membentuk model bintang. Model ini juga dikenal dengan skema data warehouse untuk analisis multidimensional, yang terdiri atas satu tabel fakta dan beberapa tabel dimensi (Fadilah et al. 2016) seperti terlihat pada Gambar 3.

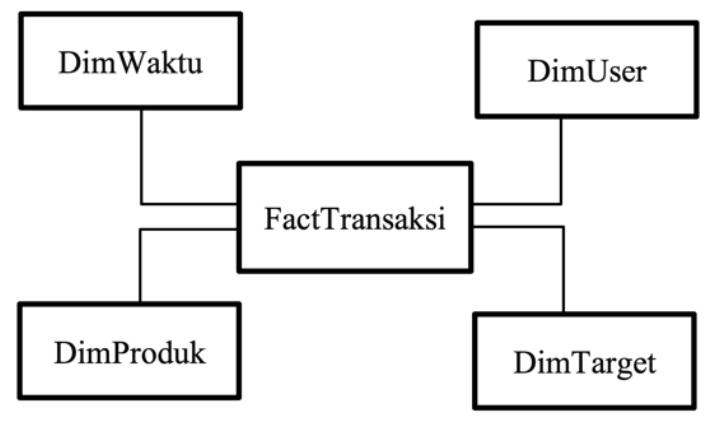

Gambar 3 Model skema bintang pada penelitian ini.

\section{HASIL DAN PEMBAHASAN}

Microsoft Power BI memungkinkan pengguna menyajikan laporan dalam berbagai macam bentuk visual. Proses penyajian tersebut disebut dengan layanan pelaporan. Dalam penelitian ini hasil layanan pelaporan dibutuhkan dalam proses pengambilan keputusan yang akan dilakukan oleh stakeholder aplikasi ApotikKuota. Proses pengambilan keputusan didasarkan pada teori dalam penerapan strategi marketing, yaitu strategi 4P bauran pemasaran. Selanjutnya informasi tersebut akan disajikan pada dashboard pelaporan berdasarkan komponen dalam bauran pemasaran (marketing mix).

\section{Komponen Harga}

Gambar 4 menunjukkan tampilan dashboard reporting komponen price (harga) yang berisikan informasi (a) total nominal transaksi pelanggan berstatus reseller berdasarkan produk per tahun, (b) total nominal transaksi untuk masing-masing operator, (c) total keuntungan berdasarkan pelanggan berstatus reseller per-tahun, dan (d) total keuntungan berdasarkan target keuntungan per-tahun. Gambar 4 bagian kiri atas menunjukkan grafik untuk produk pulsa merupakan produk yang paling banyak dijual oleh para reseller, diikuti oleh produk paket internet dan token listrik. Grafik ini menunjukkan bahwa strategi harga dapat diterapkan untuk produk pulsa, paket internet, serta token PLN.

Jika penerapan strategi harga (price) mengacu pada produk yang terlaris, proses penekanan harga dengan ambang batas bawah yang tidak terlalu jauh dapat dilakukan. Hal ini diharapkan dapat memberikan dampak peningkatan keuntungan berdasarkan kuantitas terhadap penjualan produk pulsa. Hasil akhir dari penerapan strategi harga ini adalah target keuntungan dapat tercapai. Jika penerapan strategi pemasaran ini menggunakan komponen dalam bauran pemasaran, skenario berikut dapat dilakukan: strategi promosi dapat dilakukan dengan info pemberian uang kembali ataupun poin hadiah yang dilakukan berdasarkan akumulatif terhadap transaksi pembelian produk dengan nominal tertentu yang ditentukan oleh pihak stakeholder. Potongan pembelian produk berdasarkan transaksi jumlah poin hadiah dapat dilakukan oleh pengguna reseller.

\section{Komponen Produk}

Gambar 5 dan Gambar 6 menunjukkan tampilan dashboard pelaporan komponen produk yang berisi informasi total keuntungan berdasarkan jenis produk per-kuartal dan per-tahun. Dari Gambar 6 terlihat pendapatan terkecil merupakan produk GoPay. Informasi tersebut dapat menjadi acuan dalam menambah jenis produk yang akan ditambah oleh pihak stakeholder. Paket internet masih menjadi produk favorit pengguna dalam melakukan transaksi. Jika melihat 
tren yang terjadi saat ini, penambahan produk PPOB baru pada aplikasi ApotikKuota perlu dilakukan untuk meningkatkan keuntungan yang signifikan.

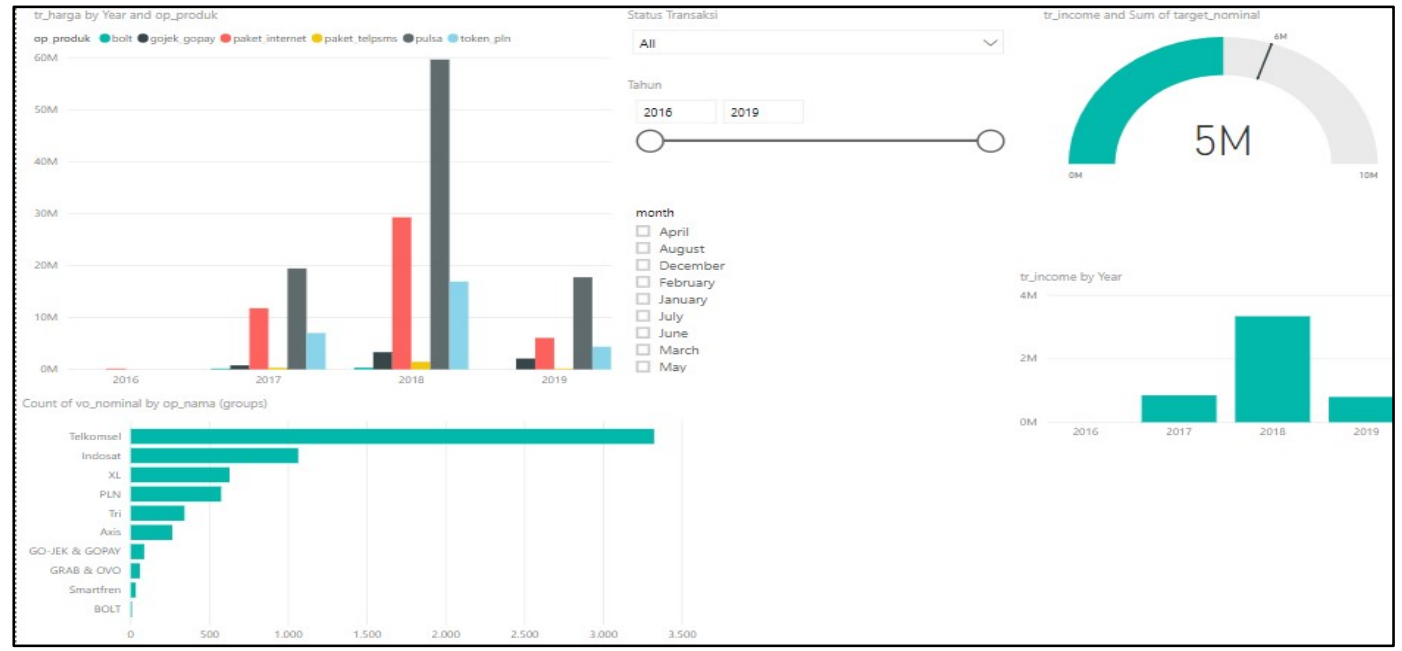

Gambar 4 Dashboard pelaporan komponen harga.

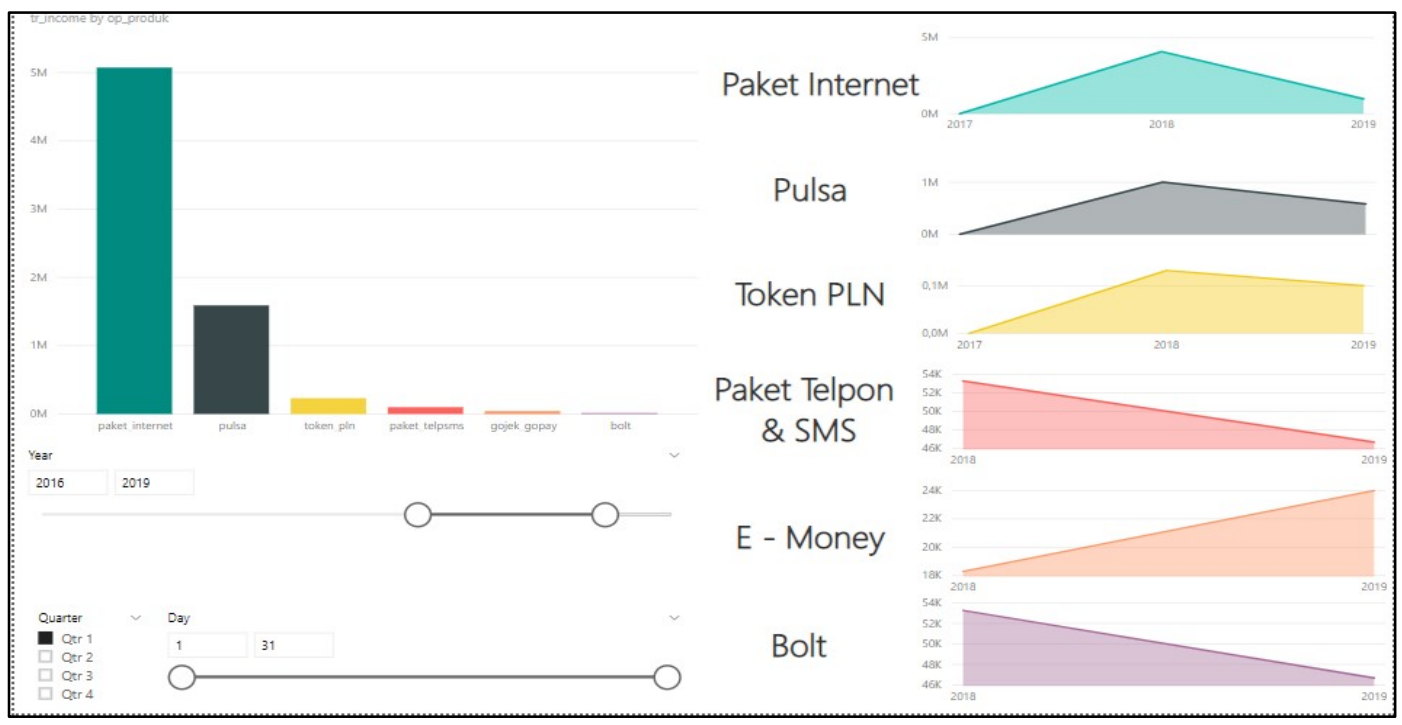

Gambar 5 Dashboard pelaporan komponen produk.

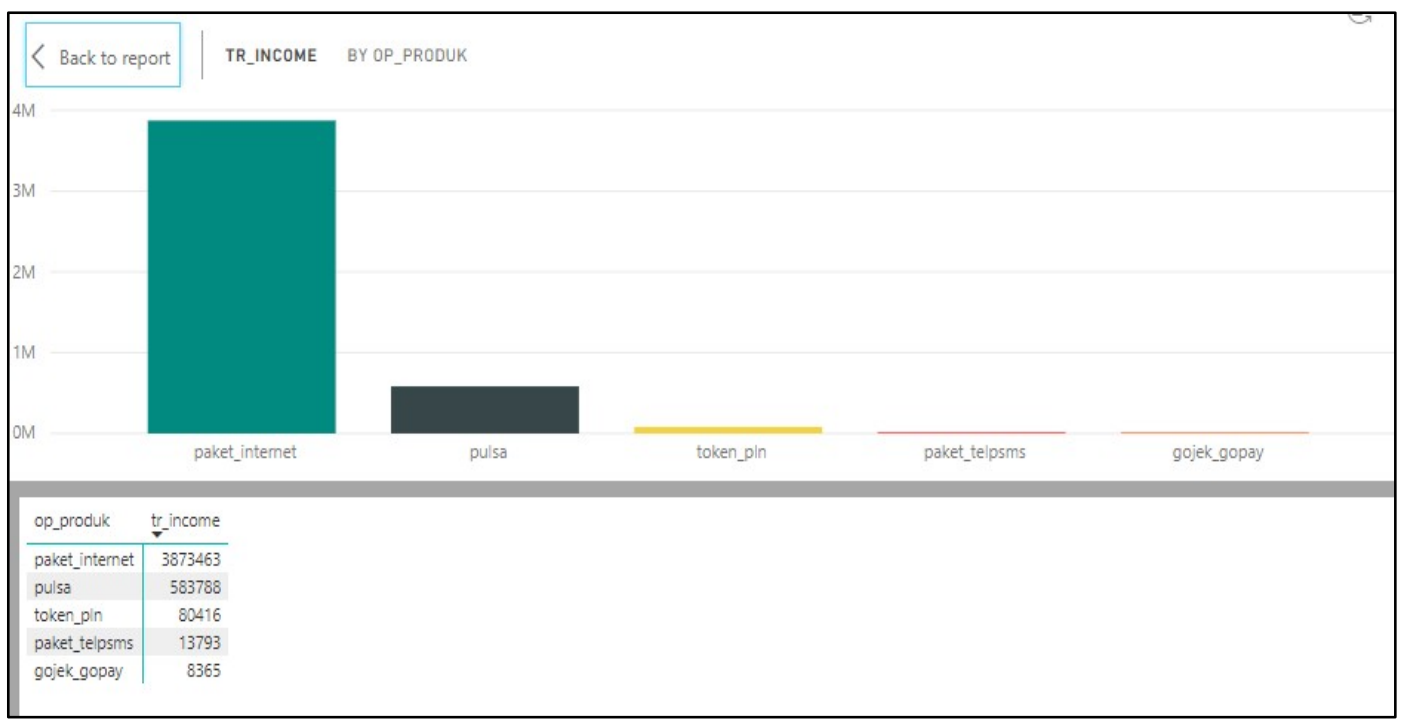

Gambar 6 Informasi detail total keuntungan berdasarkan jenis produk. 
Jika pihak stakeholder ingin menerapkan strategi produk dengan menambahkan produk PPOB, setidaknya perlu penambahan dua jenis produk. Beberapa produk PPOB yang dapat dijadikan sebagai tambahan produk pada aplikasi ApotikKuota ialah Penjualan tiket kereta api serta pesawat secara daring. Setelah itu, akan timbul pertanyaan, 'mengapa aplikasi ApotikKuota harus menambahkan produk tiket daring kereta api dan pesawat?'. Berdasarkan data Badan Pusat Statistik pada bulan februari 2019, kedua produk tersebut sangat tinggi peluangnya dikarenakan tingkat perjalanan penumpang masih tinggi (BPS 2019a).

Data tersebut memperlihatkan penumpang yang berangkat dari beberapa bandara utama di Indonesia masih sangat tinggi. Walaupun ada penurunan jumlah penumpang dikarenakan beberapa faktor seperti tinggi harga tiket pesawat, moda transportasi ini masih sangat menjanjikan. Begitu pula halnya dengan jumlah penumpang kereta api, faktor tinggi harga tiket moda transportasi udara membuat penumpang memilih moda transportas alternatif, seperti kereta api. Berdasarkan data BPS (2019b), jumlah penumpang kereta api dari tahun 2006 hingga 2019 mengalami kenaikan.

Dengan demikian, dapat diambil kesimpulan bahwa penjualan tiket secara daring untuk moda transportasi udara/pesawat dan kereta api masih sangat menjanjikan dan dapat menjadi pertimbangan pihak stakeholder aplikasi ApotikKuota untuk menambahkan kedua produk tersebut. Penambahan ini akan berdampak pada peningkatan keuntungan dari sisi produk. Jika penerapan strategi pemasaran ini menggunakan komponen dalam bauran pemasaran (marketing mix), maka dapat dibuatkan sebuah skenario seperti berikut: dalam penerapannya, strategi produk harus dilakukan secara bersamaan dengan komponen strategi promosi, strategi distribusi, serta strategi harga. Ketika produk ini siap dipasarkan, pihak stakeholder harus memberikan promosi, baik berupa uang kembali maupun hadiah poin (khusus reseller), serta harga tiket promo. Skenario ini diharapkan meningkatkan keuntungan berdasarkan transaksi yang dilakukan oleh para pengguna ApotikKuota, baik reseller, member, dan non-member.

\section{Komponen Distribusi}

Gambar 7 menunjukkan tampilan dashboard pelaporan komponen place (distribusi) yang berisikan informasi total keuntungan berdasarkan keseluruhan status pengguna per tahun. Gambar 8 menunjukkan bahwa pengguna dengan status member dan non-member memiliki tingkat total keuntungan yang tinggi berdasarkan total transaksinya dibandingkan dengan pengguna reseller. Berdasarkan hal tersebut, strategi distribusi untuk meningkatkan jumlah pengguna yang berstatus reseller perlu dilakukan.

\section{Evaluasi}

Secara umum evaluasi dari proses ETL memiliki beberapa tujuan akhir, yaitu data completeness, data transformation, dan integration testing. Evaluasi data completeness dilakukan adalah dengan melakukan verifikasi untuk memastikan semua data yang dibutuhkan dapat dimuat dalam data warehouse. Salah satunya dilakukan dengan dengan membandingkan semua nilai unik pada atribut kunci antara sumber OLTP dan data yang diisi dalam data warehouse. Evaluasi data transformation dilakukan untuk memastikan bahwa perubahan data yang dilakukan sesuai dengan kebutuhan pembangunan BI pada aplikasi ApotikKuota. Sebagai contoh, pada transaksi terdapat atribut tr_tanggal berformat UNIX yang selanjutnya akan dikonversi ke format DateTime.

Evaluasi terakhir, yaitu integration testing adalah bagian dari proses integrasi berbagai sumber untuk memastikan bahwa pembangunan BI dapat berjalan dengan baik. Sebagai contoh, saat melakukan proses integrasi untuk tabel fakta transaksi yang berhubungan dengan tabeltabel dimensi, produk, pengguna, target, dan waktu adalah dengan melakukan proses query penggabungan (join) pada standard query language (SQL). Query kemudian dijalankan untuk menghasilkan kubus data seperti yang terlihat pada Gambar 9. 
trincome by Year and us_reseller

us reseller Oactive Oinsctive Onon-member

$10 \mathrm{M}$

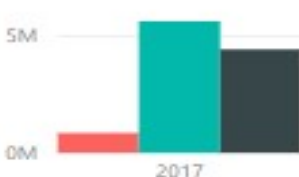

2017

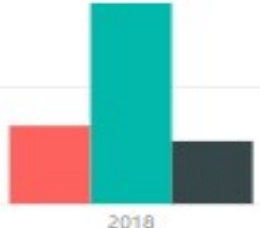

2018

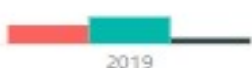

2019

Year

$2017 \quad 2020$

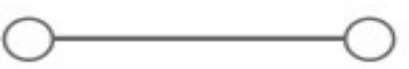

Count of us_reseller and Count of us_reseller by Year

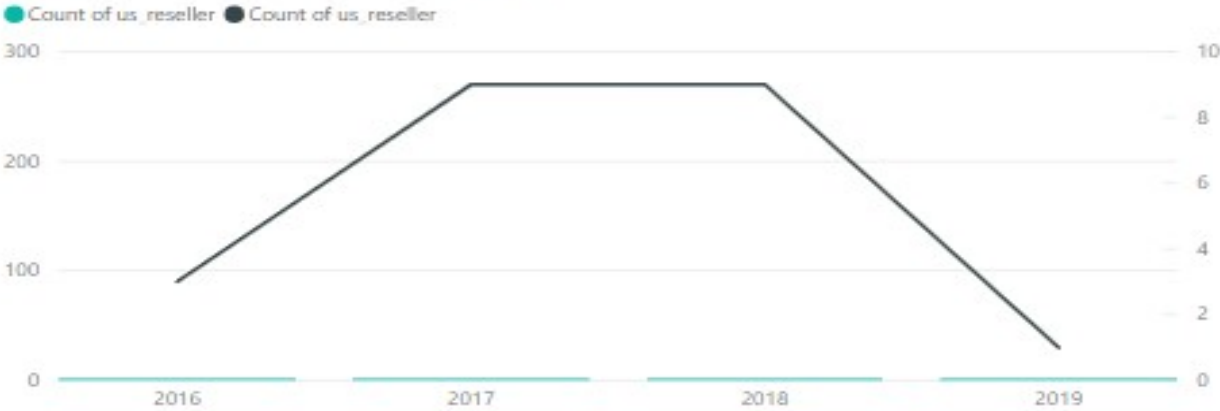

Gambar 7 Dashboard pelaporan komponen distribusi.

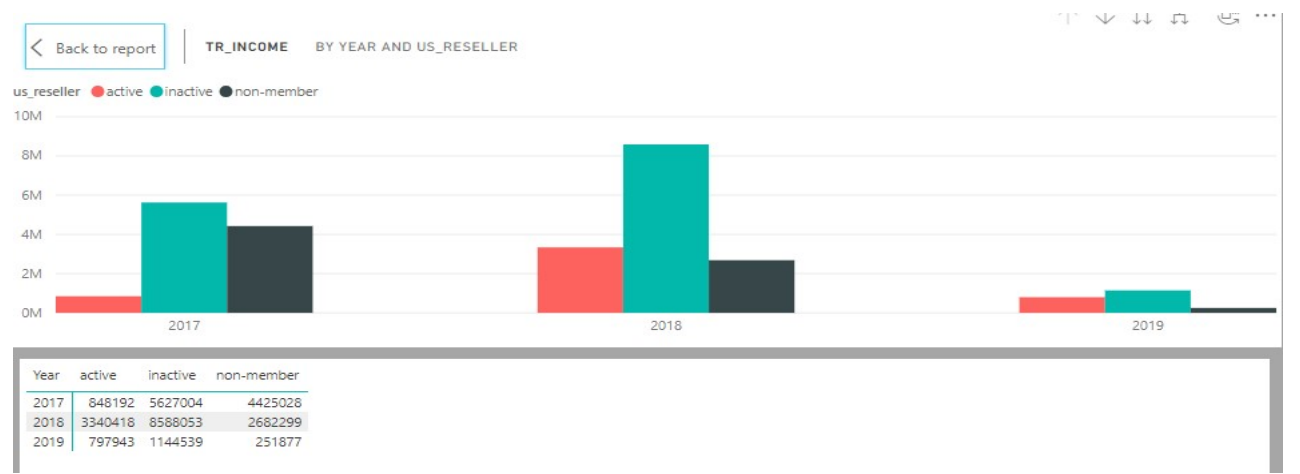

Gambar 8 Informasi detail total keuntungan berdasarkan status pengguna.

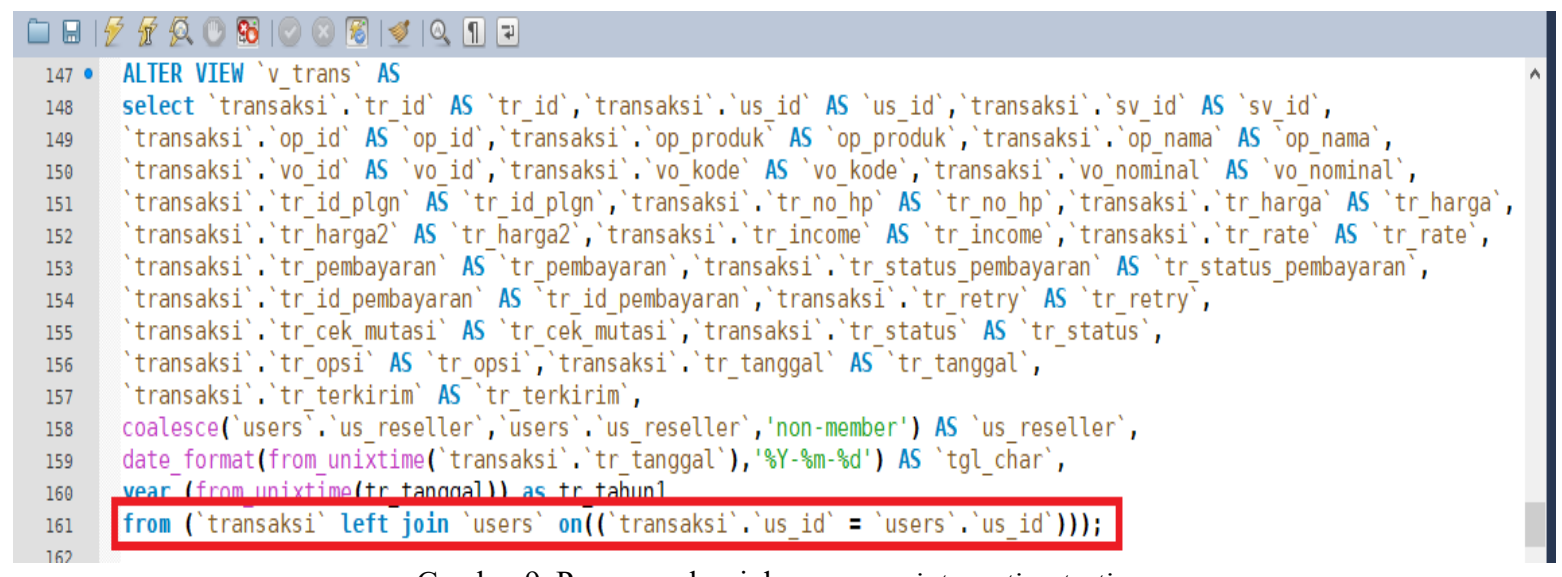

Gambar 9 Proses evaluasi dengan cara integration testing. 


\section{SIMPULAN}

Penggunaan data warehouse untuk menghasilkan sistem pelaporan yang lebih baik, jika dibandingkan dengan sistem pelaporan yang berbasis OLTP. Dalam membangun data warehouse, sumber data OLTP yang akan digunakan harus melalui proses pemilihan berdasarkan kebutuhan bisnis. Dalam hal ini yang berkaitan dengan strategi pemasaran yang akan diterapkan pada aplikasi ApotikKuota. Secara keseluruhan, hasil analisis OLAP digunakan sebagai informasi dalam penerapan strategi bauran pemasaran berdasarkan empat komponen utama ntuk menghasilkan informasi yang dibutuhkan sebagai acuan dalam pengambilan keputusan. Penggunaan Microsoft Power BI dijadikan sebagai langkah awal proses implementasi pada ApotikKuota untuk pengembangan pengolahan data di masa yang akan datang. Kemampuan dari hasil implementasi BI telah berhasil dievaluasi melalui proses ETL, yaitu data completeness, data transformation, dan integration testing.

\section{DAFTAR PUSTAKA}

[BPS] Badan Pusat Statistik. 2019a. Jumlah Penumpang yang Berangkat pada Penerbangan Domestik di Bandara Utama Indonesia, 2006-2019 (Orang) [Diakses 7 April 2019]. Tersedia di: bps.go.id/dynamictable/2015/03/10/812/jumlah-penumpang-yangberangkat-pada-penerbangan-domestik-di-bandara-utama-indonesia-2006-2019-orang.html

[BPS] Badan Pusat Statistik. 2019b. Jumlah Penumpang Kereta Api, 2006-2019 (Ribu Orang) [Diakses 7 April 2019]. Tersedia di: bps.go.id/dynamictable/2015/03/10/815/jumlahpenumpang-kereta-api-2006-2019-ribu-orang-.html

Fadilah U, Winarno WW, Amborowati A. 2016. Perancangan data warehouse untuk sistem akademik STMIK Kadiri. Jurnal Ilmiah Sistem Informasi dan Teknik Informatika (SISFOTENIKA).6(2):217-228.

Kotler P, Armstrong G. 2012. Principles of marketing channel management. Journal of Marketing. 42(4):105. doi: 10.2307/1250103.

Tim SBF (2018) Apa itu PPOB?. Diakses di fastpay.co.id/blog/apa-itu-ppob.html 